\title{
Editorial
}

\section{A Dialética entre Documentar e Fazer Frutificar Experiências e Pesquisas a Respeito do Ensino de Graduação}

Prof. Thiago Mio Salla e Prof. Eder Cassola Molina

Ao Cosmonauta Chico*

Com esta edição, a Revista de Graduação da USP, ou simplesmente Grad+, celebra seu segundo ano de vida. Num rápido balanço, até o presente momento publicamos 43 artigos e 79 relatos, conjunto este que não apenas documenta os múltiplos e incansáveis esforços de professores e pesquisadores quanto ao aprimoramento do ensino de graduação, mas também se frutifica em novas pesquisas (teóricas e empíricas), debates e compartilhamento de experiências pedagógicas e práticas nos mais variados campos de conhecimento.

Desde seu número inaugural, num esforço de proporcionar um fórum amplo de debates, Grad+ procura contemplar trabalhos oriundos das três grandes áreas do saber os quais, por sua vez, mostramse capazes, em certo sentido, de serem replicados em outros contextos. Como de praxe, neste número 6, não fugimos a essa regra. Logo de saída, destaque para o artigo de capa "Interdisciplinaridade em Bacharelado no Brasil: o Caso de Relações Internacionais da USP", no qual se discutem os desafios da integração interdisciplinar nos cursos de graduação, tendo em vista a discussão de um caso específico. Valendo-se de técnicas de mineração de textos que tomam como objeto de análise os conteúdos programáticos das disciplinas obrigatórias e as escolhas de disciplinas optativas feitas pelos discentes, as autoras procuraram avaliar o grau de interdisciplinaridade do bacharelado em Relações Internacionais da USP e chegaram a conclusão de que, embora avanços sejam observados ao longo do tempo, o curso ainda precisa se aprimorar nesse quesito.

Logo em seguida, em "Formação Moral e Ética nos Cursos de Graduação", Caio César Coelho Rodrigues (FGV) e Ricardo Leite Camargo (Esalq/USP) procuram analisar as concepções de "projeto de vida" e de "sucesso profissional" que se fazem presentes no âmbito de um bacharelado em Administração. Nesse processo, os autores observaram, em chave mais ampla, que a universidade costuma associar o conceito de sucesso profissional ao êxito na educação técnica, deixando em segundo plano a discussão a respeito da interseção entre o projeto de vida pessoal do aluno e a preocupação com o "outro". Diante dessa constatação, destacam a importância de as Instituições de Ensino Superior discutirem tal estado de coisas de modo a aperfeiçoarem a formação ética e moral no âmbito da graduação.

Em "O Ensino Superior e a Formação de Professores com Ênfase nas Engenharias", ganha destaque a importância da educação em engenharia como área de conhecimento. Mais especificamente, a partir da demanda da sociedade por engenheiros mais bem qualificados, os autores do artigo (ambos da Poli/USP) sinalizam que a formação de profissionais com competências transversais requer uma série de transformações no conjunto das aulas ministradas, algo que, por sua vez, passa por mudanças na formação do corpo docente e por modificações institucionais.

* Francisco Ferreira Salla, belo garoto de olhos sagazes que aportou neste planeta em meados de maio último, enquanto terminava a gestação deste número de Gradt. Eleito nosso editor-mirim honorário, carrega consigo nosso desejo de que ele possa rabiscar inumeráveis provas de diagramação das futuras edições da revista. 
Ainda quanto aos artigos da presente edição, com o fito de examinar as interfaces entre tecnologia, mídia e ensino, Marciel A. Consani (ECA/USP) problematiza o conceito de "Mediação Tecnológica na Educação", valendo-se de diferentes aportes teóricos e práticos. Nesse movimento, acaba por fornecer mais elementos para a compreensão do emprego das TIC's em sala de aula. E por falar em tal perspectiva que vem provocando mudanças profundas nos os papéis tradicionais exercidos por professores e alunos, um pool de pesquisadores da USP de Ribeirão Preto apresenta os resultados de estudo que procurou analisar o emprego da Webquest (proposta investigativa na qual os alunos interagem com dados provenientes da internet) tendo em vista o gerenciamento de custos aplicados à enfermagem hospitalar. Entre outros aspectos, os autores do estudo constaram os benefícios de tal metodologia no desenvolvimento de competências relacionadas ao processo de tomada de decisão.

O emprego de metodologias ativas de ensino-aprendizagem também avulta em artigo de Roberto Portes Ribeiro (UFSM) e Adriana Backx Noronha Viana (FEA/USP) que trata do uso do PBL (Problem Based Learning) em disciplinas da graduação em Administração. Nesse trabalho, os autores discorrem sobre as definições conceituais do PBL sem perder de vista o estabelecimento de ações para subsidiar a estruturação de tal método, sempre tendo em vista a criação de um ambiente de aprendizagem flexível capaz de integrar teoria e prática empresarial.

De modo análogo, com o objetivo de avaliar o impacto de abordagens pedagógicas passíveis de engajar os alunos na resolução de questões práticas, Leonardo Guimarães Garcia (FFGLRP/USP) apresenta os resultados de uma Pesquisa-Ação de fôlego (realizada ao longo de quatro anos). Em tal estudo, ele comparou o ensino da atividade de "formulação de estratégias" no curso de Biblioteconomia e Ciência da Informação da FFCLRP/USP antes e depois da implementação de mudanças que procuraram elevar os discentes à condição sujeitos do próprio aprendizado. De um modo geral, os resultados indicam que os aperfeiçoamentos realizados na disciplina contribuíram para a melhoria do aprendizado técnico dos alunos

Por fim, na seção de relatos, de acordo com a lógica de conferir unidade ao disperso, procuramos oferecer ao leitor uma miríade de textos a respeito de diversificadas pesquisas, experiências e práticas de ensino realizadas por docentes e pesquisadores dos mais variado cursos e áreas do saber. Entre outros relatos aqui recolhidos, há o que trata do ensino de Física a partir da contextualização de conceitos científicos; o que analisa o impacto do trabalho realizado por alunos de graduação no Coral da USP Ribeirão Preto; o que, a partir de uma ponte entre universidade-escolas públicas de nível básico, investiga o fenômeno do bullying; o que partilha o esforço de implantação de uma ferramenta conversacional voltada, entre outros aspectos, para a construção conjunta, docente-estudante, do programa e do formato das disciplinas; o que destaca a utilização do Sistema Único de Saúde (SUS) como cenário pedagógico, permitindo ao aluno de Odontologia vivenciar e dialogar com a realidade in loco; e o que descreve a utilização de técnicas participativas com vistas a compreensão do processo de judicialização da saúde.

Enfim, tanto entre os artigos quanto entre os relatos, temos aqui o tratamento de um rol extenso de temas, práticas, abordagens e perspectivas que atestam quer o vigor de experiências docentes já consolidadas, quer, sobretudo, a validade de propostas inovadoras relativas ao ensino de graduação nos mais diversos campos de conhecimento. Caixa de ressonância de tal material, Grad+ segue não apenas conferindo unidade à tamanha pluralidade, mas também permitindo que ela se frutifique em novos saberes, novos debates, novas práticas e, além, na gestação de novos indivíduos. 